Determination of recovered Cadmium and Nickel from spent alkaline batteries using acidic solutions and AAS measurements

\author{
Ahmed M. Saeed, Areej A. Jarullah and Mohammed J. Mohammed
}

\title{
Determination of recovered Cadmium and Nickel from spent alkaline batteries using acidic solutions and AAS measurements
}

\author{
Ahmed M. Saeed, Areej A. Jarullah and Mohammed J. Mohammed \\ University of Diyala - College of Science - Chemistry department
}

Received 27 July 2016 ; Accepted 25 August 2016

\begin{abstract}
$\underline{\text { Abstract }}$
This research include the recovery study of cadmium and nickel from spent alkaline batteries was conducted by two different acidic solutions. The first one is nitric acid, which was used for cadmium recovery; the other is sulfuric acid, which was used for nickel recovery. Many factors affected the recovery process were studied, such as concentration, volume, time, weight and temperature. The parameters which effect on the precipitation of metal ion from leaching solution were also studied, such as $\mathrm{pH}$, time, concentration and temperature. The recovery percentages of metal ion were found to be $98.5 \%$ of cadmium using optimum conditions ( $5 \mathrm{M} \mathrm{HNO}_{3}, 2 \mathrm{gm}$ sample, $2 \mathrm{hr}$, and $20 \mathrm{ml}$ acid volume) and $99 \%$ for nickel using ( $5 \mathrm{M} \mathrm{H}_{2} \mathrm{SO}_{4}, 2 \mathrm{gm}$ sample, $2 \mathrm{hr}$, and $20 \mathrm{ml}$ acid volume). The precipitation processes were carried out using $(2 \mathrm{M} \mathrm{NaOH})$ solution. The precipitation percentages were found to be $98.6 \%$ and $99.1 \%$ of cadmium and nickel respectively. The purification processes were conducted using double distilled water. The purity of products $\mathrm{Cd}(\mathrm{OH})_{2}$ and $\mathrm{Ni}(\mathrm{OH})_{2}$ was found to be $98.08 \%$ and $98.23 \%$ respectively. The concentration of metal ion in the solutions was measured using AAS; the method was linear with $\mathrm{R}^{2}$ of (0.9995 and 0.9993) for $\mathrm{Ni}$ and Cd respectively.
\end{abstract}

Key words: Determination, Alkaline batteries, AAS, Cadmium, Nickel. 


\title{
DIYYLAL JOURNAL FOR PURE SCIENCES
}

\section{Determination of recovered Cadmium and Nickel from spent alkaline batteries using acidic solutions and AAS measurements}

\author{
Ahmed M. Saeed, Areej A. Jarullah and Mohammed J. Mohammed
}

\author{
تقدير الكادميوم والنيكل المستردة من البطاريات القاعدية المستهلكة باستخدام محاليل حامضية \\ وقياسات الامتصاص الذري \\ احمد مهذي سعيد ، أريج علي جار الله و محمد عبد الجبار محمد

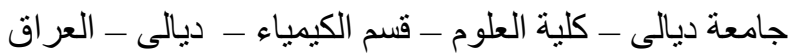

\section{الخلاصة}

هذا البحث يتضمن در اسة عملية استرداد الكادميوم و النيكل من البطاريات القاعدية المستهلكة باستخدام نوعين من المحاليل الحامضية المختلفة. النوع الاول هو حامض النتريك والذي تم استخدامه لعملية استرداد الكادميوم؛ اما النوع الثاني فهو حامض الكبريتيك و الذي تم استخدامه لاسترداد النيكل. لقد تم دراسة عدد من العو امل التي تؤثر على عملية الاسترداد مثل

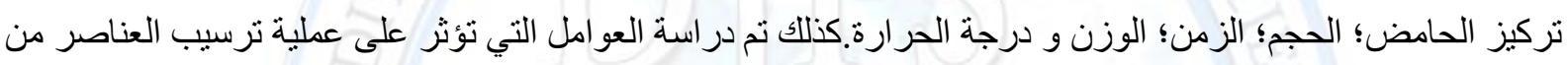
محلول الاسترداد مثل الدالة الحامضية؛ زمن الترسيب؛ التركيز و درجة الحر ارة. لقد كانت نسب الاسترداد للعناصر بحدود 98.5\% للكادميوم باستخدام الظروف المثلى ( تركيز حامض النتريك 5 مو لاري؛ وزن النموذج 2 غر ام؛ زمن الاسترداد 2 ساعة وحجم الحامض 20 مللتر)؛ كما ان نسبة الاسترداد للنيكل كانت 99\% عند استخدام الظروف المنلى (تركيز حامض الكبريتيك 5 مو لاري؛ وزن النموذج 2 غرام؛ زمن الاسترداد 2 ساعة وحجم الحامض 20 مللتر). لقد تم اجراء عملية

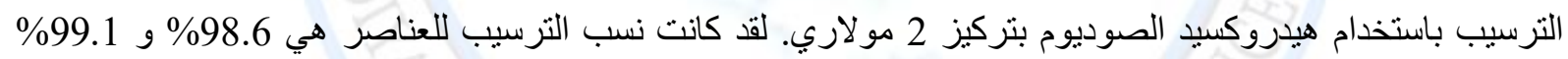

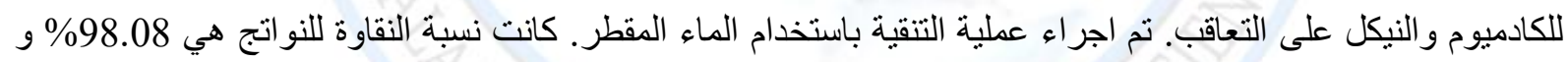
98.23\% لكل من هيدروكسيد الكادميوم وهيدروكسيد النيكل على التعاقب. تم قياس تراكيز العناصر باستخدام تقنية الامتصاص الذري وكانت قيمة R للطريقة هي (0.9993 و 0.9995) للكادميوم و النيكل على التعاقب. الكلمات المفتاحية : تقدير ، البطاريات القاعدية، الامنصاص الذري، الكادميوم ، النيكل.

\section{Introduction}

Cadmium - Nickel power supplies account for about $10 \%$ of all chemical current sources in use [1]. Various conventional methods for the disposal of the spent batteries which were used in the recent past involve methods such as disposition, stabilization and recycling processes. [2]. Recycling that constitutes the most generally acceptable environmentally friendly method of managing these wastes must be taken seriously, to minimize 


\section{Determination of recovered Cadmium and Nickel from spent alkaline batteries using acidic solutions and AAS measurements}

\section{Ahmed M. Saeed, Areej A. Jarullah and Mohammed J. Mohammed}

environmental toxicity, for economic gains and a reduction in dependence on foreign resources or on virgin materials for productions in the industry as well as for the sustainability of the natural resources [3]. Any recycling technology that is developed should therefore be designed so as to fully recover these metals in the finished product, thus preventing the formation of gaseous emissions and keeping these metals out of waste water [4]. Hydrometallurgical routes are commonly found more economical and efficient than pyrometallurgical ones. Hydrometallurgy has the advantage of working at low temperature for use of aqueous solutions generates little waste gas. The hydrometallurgical technologies that can be used for recycling mainly entail converting metals to a solution by basic or acid leaching. The metals can be recovered from the solution by precipitation, electrolysis, or liquid extraction [5 - 9]. In recent years, numerous studies on the treatment, recycling and determination of metals in batteries by hydrometallurgical processes and AAS mesurements have been performed [10 - 22]. In the present study a hydrometallurgical method for cadmium and nickel recovery from spending batteries was developed using an acidic medium for leaching process and basic medium for precipitation of recovered metals from leaching solutions as metal hydroxide. The obtained precipitates were purified using an aqueous solution.

\section{$\underline{\text { Experimental }}$}

\section{1 - Apparatus:}

Sartorius balance (Germany), pH meter (Germany), Stirring Hotplate (Korea), Sonic bath (Korea)، Shaking water bath (Taiwan), Furnace (Germany) and Atomic absorption (AURORA - Canada) were used through this study.

\section{2 - Materials and reagents:}

$\mathrm{Ni}-\mathrm{Cd}$ batteries were supplied from Iraqi electrical power stations. All other chemicals used in the present study were of analytical grade reagents unless otherwise stated. Sulfuric acid (BDH), Hydrochloric acid (BDH), Nitric acid (BDH), Sodium hydroxide (GCC), Potassium hydroxide (GCC), Sodium carbonate (GCC), Sodium bicarbonate (GCC) and Ammonium hydroxide $(\mathrm{BDH})$. 


\section{Determination of recovered Cadmium and Nickel from spent alkaline batteries using acidic solutions and AAS measurements}

\section{Ahmed M. Saeed, Areej A. Jarullah and Mohammed J. Mohammed}

\section{3 - Stock solutions (6M, 2M, 20\%) of acid and base:}

These solutions were prepared in volumetric flask of $1 \mathrm{~L}$ volume for each solution by the gradual dilution of concentrated solutions of acid and base by dilution law. These solutions are (6 M sulfuric acid, 2M nitric acid, 2M hydrochloric acid, 2M sodium hydroxide, 2M potassium hydroxide, 2M sodium bicarbonate, 2M sodium carbonate and $20 \%$ ammonium hydroxide). The more dilution solutions were preparation by dilution law.

\section{4 - Recovery of electrode materials:}

The components of spent alkaline batteries were separated manually. An anode (negative electrode) which contains cadmium was leaching with nitric acid, while the cathode (positive electrode) which contains nickel (Table 1, illustrate the chemical analysis of electrode powder ) was leaching using sulfuric acid. The leach solutions which contain (cadmium and iron) or (nickel and iron) were filtered and diluted. After dilution the $\mathrm{pH}$ of the solutions was adjusting up to 3 to remove iron from mother liquor solutions. The leach solutions which are iron free and contain cadmium or nickel were further used for the precipitation of $\mathrm{Cd}$ and $\mathrm{Ni}$ as hydroxide at $\mathrm{pH} 10.5$ and 11 respectively, using $2 \mathrm{M}$ sodium hydroxide solution. The hydroxides of metals were purified with double distilled water to remove sodium nitrate and sodium sulfate from precipitates.

Table. 1: Chemical analysis of electrode powder.

\begin{tabular}{|c|c|c|c|}
\hline Percentage of metals & $\mathrm{Ni} \%$ & $\mathrm{Cd} \%$ & $\mathrm{Fe} \%$ \\
\hline Type of sample & & & \\
\hline Nickel sample & 43.00 & 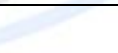 & 0.50 \\
\hline Cadmium sample & & 50.00 & 1.50 \\
\hline
\end{tabular}

\section{5 - Calibration graph and linearity study:}

For determining the linearity, a series of solutions have a different metal ions concentration range of $(1,2,3,4,5,6,8,10,12$ and $15 \mathrm{ppm})$ were prepared by simple dilution of stock solutions. The absorbance of these solutions was measured at (228.8 and 236.0) $\mathrm{nm}$ for Cd and Ni respectively. The calibration curves were obtained by plotting absorbance versus known 
Determination of recovered Cadmium and Nickel from spent alkaline batteries using acidic solutions and AAS measurements

\section{Ahmed M. Saeed, Areej A. Jarullah and Mohammed J. Mohammed}

concentrations in ppm. Figure 1, illustrate the calibration graph $\mathrm{Ni}$ and $\mathrm{Cd}$ by Atomic absorption spectroscopy (AAS). The method were linear with an $\mathrm{R}^{2}$ of (0.9995 and 0.9993) for Ni (II) and Cd (II) respectively. Linearity was determined by the regression analysis. The obtained results were tabulated in Table 2 , shows that the value of $t_{c a l}$ is larger than $t_{t a b}$ value, and $R^{2}$ values are $(0.9995$ and 0.9993$)$, which indicating that there is a strong correlation between the variation of concentration and response.

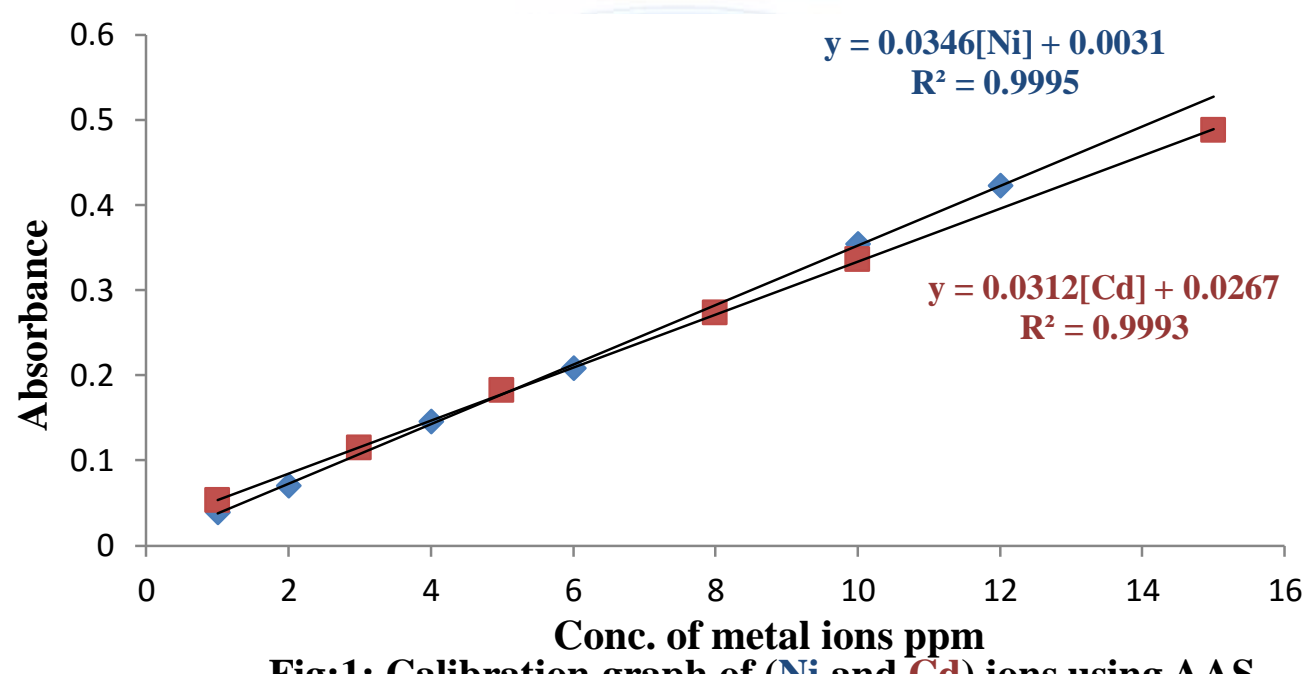

Fig:1: Calibration graph of (Ni and Cd) ions using AAS

Table.2: Summary of linear regression for the variation of absorbance with metal ions concentration using first degree equation of known form $y=b[X]+a$.

\begin{tabular}{|l|l|l|l|l|l|}
\hline $\begin{array}{l}\text { Type of } \\
\text { metal ion }\end{array}$ & $\begin{array}{l}\text { Linear } \\
\text { range } \\
\mathbf{p p m}\end{array}$ & $\begin{array}{l}\text { Straight line equation } \\
\mathbf{A b s .}=\mathbf{b}[\mathbf{X}]+\mathbf{a}\end{array}$ & $\begin{array}{l}\text { Correlation } \\
\text { coefficient } \\
(\mathbf{r})\end{array}$ & $\begin{array}{l}\text { Percentage } \\
\text { linearity } \\
\left(\mathbf{r}^{\mathbf{2} \%)}\right.\end{array}$ & $\begin{array}{l}\text { Calculated } \\
(\mathbf{t}) \text { values } \\
\mathbf{t} \text { cal. }=\frac{/ \boldsymbol{r} / \sqrt{\boldsymbol{n}-\mathbf{2}}}{\sqrt{\mathbf{1 - r ^ { 2 }}}}\end{array}$ \\
\hline $\mathrm{Ni}$ (II) ion & $1-12$ & $\begin{array}{l}\mathrm{y}=0.0346[\mathrm{Ni}]+ \\
0.0031\end{array}$ & 0.9997 & 99.95 & $\begin{array}{l}89.26 \\
2.78\end{array}$ \\
\hline $\mathrm{Cd}$ (II) ion & $1-15$ & $\begin{array}{l}\mathrm{y}=0.0312[\mathrm{Cd}]+ \\
0.0267\end{array}$ & 0.9996 & 99.93 & $79.89 \gg 2.78$ \\
\hline
\end{tabular}


Determination of recovered Cadmium and Nickel from spent alkaline batteries using acidic solutions and AAS measurements

\section{Ahmed M. Saeed, Areej A. Jarullah and Mohammed J. Mohammed}

\section{$\underline{\text { Results and Discussions }}$}

\section{1 - Recovery studies:}

\section{1 - Study of the leaching solution type:}

In this set of experiments the investigation of the leaching solution type was studied. Different types of solutions were used to carry out this study. The solutions have a concentration of $2 \mathrm{M}\left(\mathrm{H}_{2} \mathrm{SO}_{4} \cdot \mathrm{HNO}_{3} \cdot \mathrm{HCl} \cdot \mathrm{NaOH} \cdot \mathrm{NaHCO}_{3}, \mathrm{KOH} \cdot \mathrm{Na}_{2} \mathrm{CO}_{3}\right)$ was used for recovery of metal ion as shown in Table 3 and Figure 2. The results obtained revealed that the highest recovery values were occurring with the acidic solution, while the lowest values occurred with the basic solution. The highest recovery percentage of cadmium was found to be $61.2 \%$ of nitric acid solution, while the highest recovery percentage of nickel was $92.56 \%$ of sulfuric acid solution.

The recovery percentage was calculated as follows:

$\%$ recovery $=\frac{\text { metal in solution }(m g)}{\text { metal in sample }(m g)} \times 100$

Table. 3: Recovery percentage of Nickel and Cadmium for several type of solution.

\begin{tabular}{|c|c|c|}
\hline Type of solution & \% Ni recovery & \% Cd recovery \\
\hline $\mathrm{H}_{2} \mathrm{SO}_{4}$ & 92.56 & 52.00 \\
\hline $\mathrm{HNO}_{3}$ & 85.58 & 61.20 \\
\hline $\mathrm{HCl}$ & 84.69 & 61.00 \\
\hline $\mathrm{NaOH}$ & 0.120 & 3.64 \\
\hline $\mathrm{KOH}$ & 0.016 & 3.16 \\
\hline $\mathrm{NaHCO}_{3}$ & 0.002 & 2.80 \\
\hline $\mathrm{Na}_{2} \mathrm{CO}_{3}$ & 0.001 & 0.24 \\
\hline
\end{tabular}


Determination of recovered Cadmium and Nickel from spent alkaline batteries using acidic solutions and AAS measurements

Ahmed M. Saeed, Areej A. Jarullah and Mohammed J. Mohammed

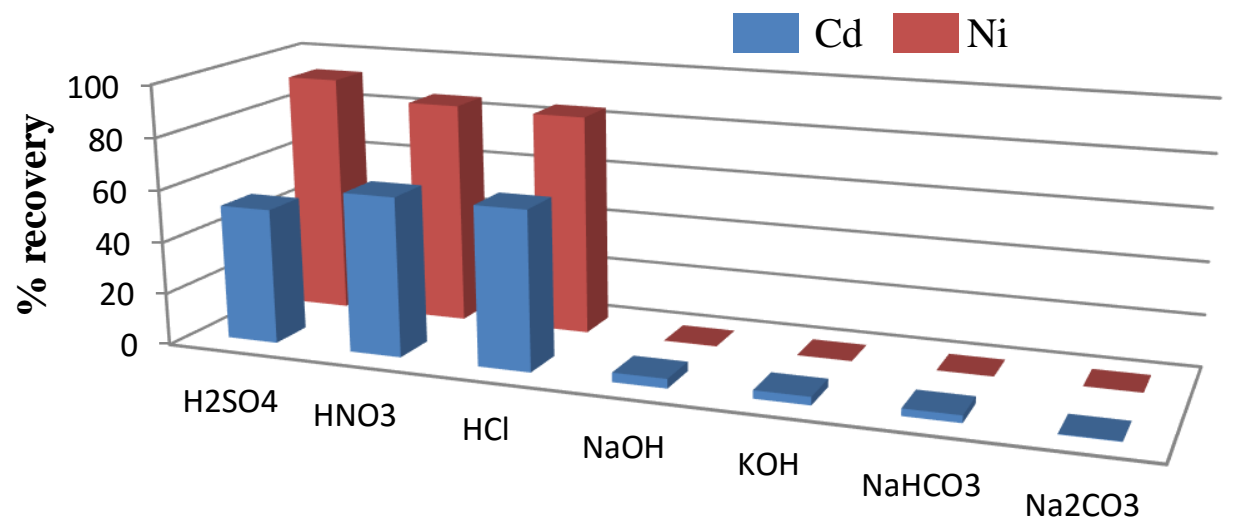

Type of solution

Fig. 2: relationship between type of solution Vs. recovery

\section{2 - Effect of leaching solution concentration:}

In this study the effect of solution concentration on recovery of $\mathrm{Cd}$ and $\mathrm{Ni}$ was investigated.

Different solutions of nitric acid and sulfuric acid have a concentration of $(1,2,3,4,5,6)$ $\mathrm{M}$ were used for the recovery of $\mathrm{Cd}$ and $\mathrm{Ni}$ respectively (table 4 and figure 3). The obtained results indicate that the recovery percentages were increased as the concentration of solutions of acid was increased until reaching $5 \mathrm{M}$, after that the value of increasing being small or near constant value.

Table. 4: the obtained results from solution concentration study.

\begin{tabular}{|c|c|c|}
\hline Acid conc. mol. / I & \% Ni recovery & \% Cd recovery \\
\hline 1 & 18.90 & 5.50 \\
\hline 2 & 50.00 & 10.00 \\
\hline 3 & 68.30 & 26.50 \\
\hline 4 & 80.10 & 53.50 \\
\hline 5 & 89.10 & 78.00 \\
\hline 6 & 89.20 & 78.30 \\
\hline
\end{tabular}


Determination of recovered Cadmium and Nickel from spent alkaline batteries using acidic solutions and AAS measurements

Ahmed M. Saeed, Areej A. Jarullah and Mohammed J. Mohammed

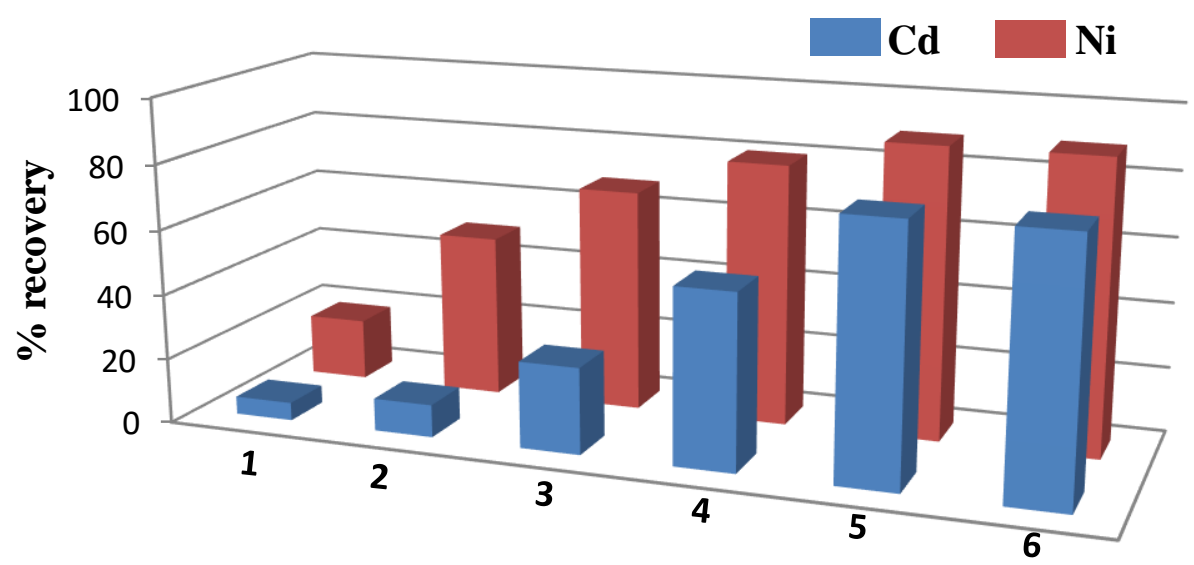

Conc. mol/l

Fig: 3: relationship between conc. of acid Vs. recovery

\section{3 - Effect of solution volume:}

This study was carried out using different volumes of acid $(5,10,15,20,25 \mathrm{ml})$ which have a concentration of $5 \mathrm{M}$. The results obtained are tabulated in table 5 , which revealed that the recovery percentages were increased as the volume of solutions of acid was increased until reaching $20 \mathrm{ml}$, after that the value of increasing being small or near constant value as shown in figure 4.

Table. 5: the obtained results from solution volume study.

\begin{tabular}{|c|c|c|}
\hline Acid volume. ml. & \% Ni recovery & \% Cd recovery \\
\hline 5 & 18.75 & 13.00 \\
\hline 10 & 64.76 & 34.00 \\
\hline 15 & 79.66 & 67.60 \\
\hline 20 & 89.18 & 90.20 \\
\hline 25 & 89.30 & 90.00 \\
\hline
\end{tabular}


Determination of recovered Cadmium and Nickel from spent alkaline batteries using acidic solutions and AAS measurements

Ahmed M. Saeed, Areej A. Jarullah and Mohammed J. Mohammed

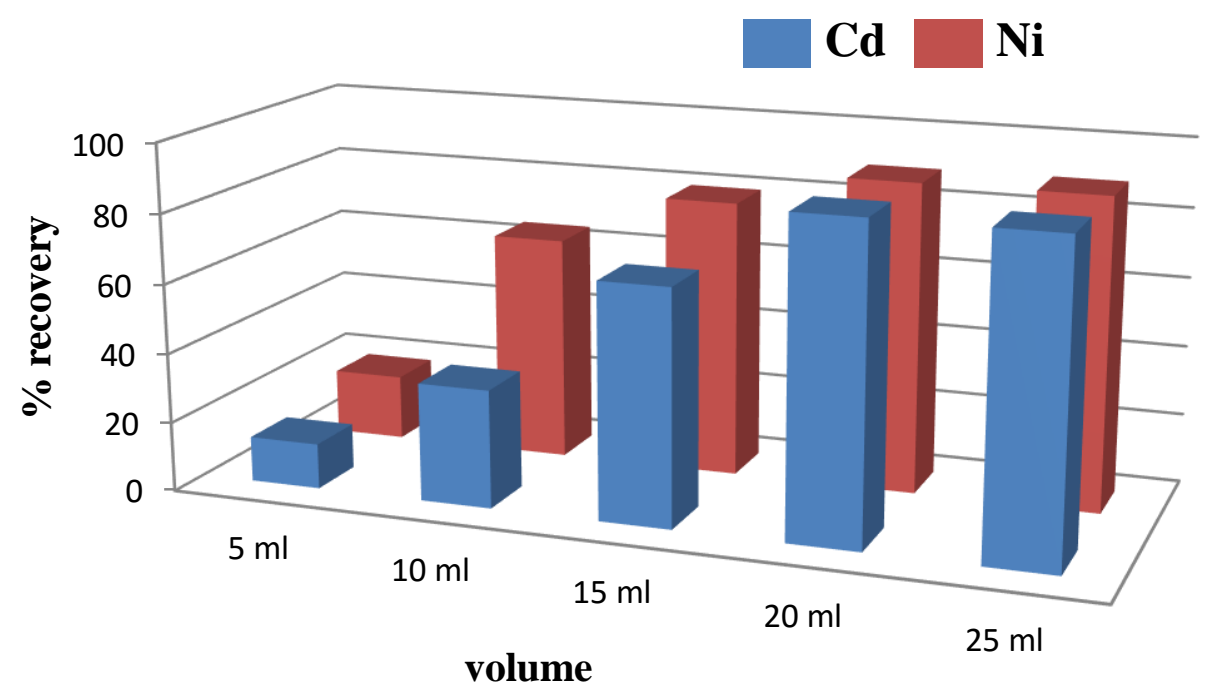

Fig: 4: relationship between acid volume Vs. recovery

\section{4 - Effect of leaching time:}

In this study the effect of leaching time on recovery of $\mathrm{Cd}$ and $\mathrm{Ni}$ was investigated. The solutions of nitric acid and sulfuric acid have a concentration of $5 \mathrm{M}$ were used for the recovery of $\mathrm{Cd}$ and $\mathrm{Ni}$ respectively, at different time (table 6 and figure 5). The obtained results indicate that the recovery percentages were increased at the time of leaching was increased until reaching $120 \mathrm{~min}$., after that the value of increasing being small.

Table. 6: the obtained results from leaching time study.

\begin{tabular}{|c|c|c|}
\hline Leaching time min. & \% Ni recovery & \% Cd recovery \\
\hline 15 & 25.53 & 28.00 \\
\hline 30 & 66.72 & 46.50 \\
\hline 60 & 89.18 & 77.50 \\
\hline 90 & 92.32 & 83.00 \\
\hline 120 & 95.58 & 90.50 \\
\hline 180 & 95.69 & 90.30 \\
\hline
\end{tabular}


Determination of recovered Cadmium and Nickel from spent alkaline batteries using acidic solutions and AAS measurements

Ahmed M. Saeed, Areej A. Jarullah and Mohammed J. Mohammed

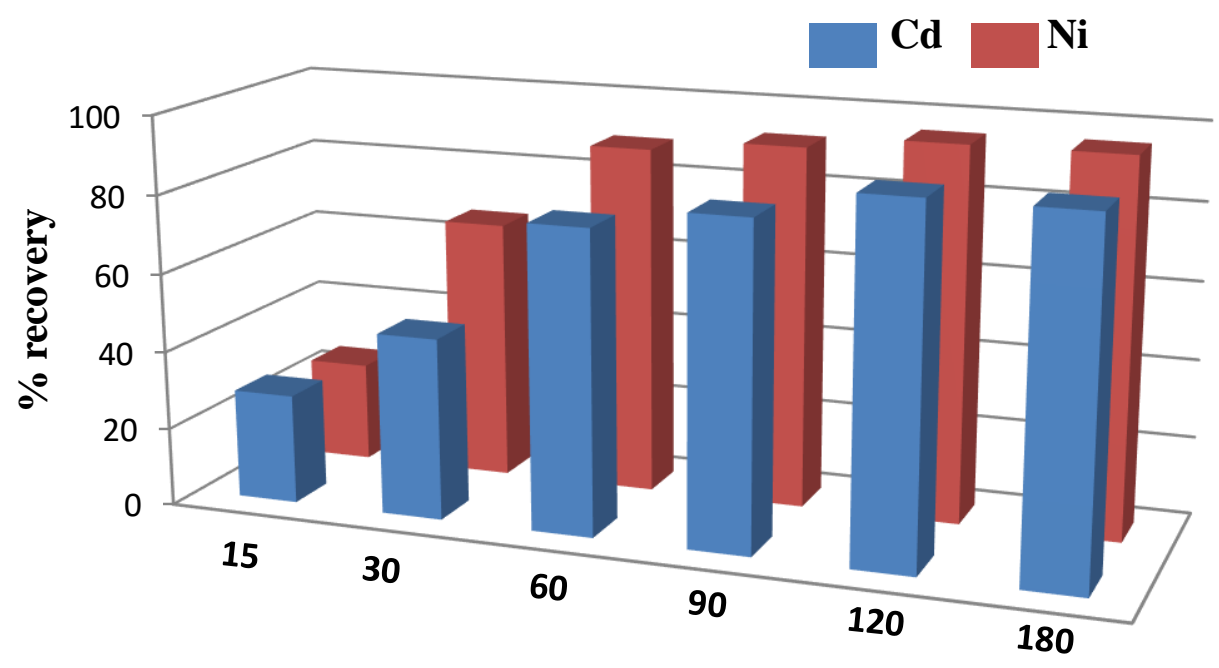

Time min.

Fig: 5: relationship between leaching time Vs. recovery

\section{5 - Effect of sample weight:}

This study was carried out using different weight of sample $(0.1,0.5,1,1.5,2,3 \mathrm{gm})$ using $20 \mathrm{ml}$ of $5 \mathrm{M}$ acid solutions. The results obtained are tabulated in table 7, which revealed that the metals in samples were recovered with high recovery percentages until reached 2 gm weight of sample and then the recovery percentages were decreased as samples weight increase, that may be due to the volume of acid is not efficient enough to dissolve the sample. So the considered ratio of weight to volume in this research was $2 \mathrm{gm} / 20 \mathrm{ml}$.

Table. 7: the obtained results from sample weight study.

\begin{tabular}{|c|c|c|}
\hline Sample weight gm. & \% Ni recovery & \% Cd recovery \\
\hline 0.10 & 98.83 & 98.00 \\
\hline 0.50 & 99.06 & 98.00 \\
\hline 1.00 & 99.0 & 97.8 \\
\hline 1.50 & 98.75 & 97.3 \\
\hline 2.00 & 97.50 & 97.00 \\
\hline 3.00 & 64.72 & 63.73 \\
\hline
\end{tabular}




\section{DIYALA JOURNAL FOR PURE SCIENCES}

Determination of recovered Cadmium and Nickel from spent alkaline batteries using acidic solutions and AAS measurements

\section{Ahmed M. Saeed, Areej A. Jarullah and Mohammed J. Mohammed}

\section{6 - Effect of temperature:}

In this study the effect of leaching temperature on recovery of $\mathrm{Cd}$ and $\mathrm{Ni}$ was investigated. The solutions of nitric acid and sulfuric acid have a concentration of $5 \mathrm{M}$ were used for the recovery of $\mathrm{Cd}$ and $\mathrm{Ni}$ respectively, at different temperatures (table 8 and figure 6). The obtained results indicate that the recovery percentages were increased as the temperature of leaching was increased until reaching $70^{\circ} \mathrm{C}$, after that the value of increasing being small or decreased due to the re-precipitation process which occurs at high temperature.

Table. 8: the obtained results from temperature study.

\begin{tabular}{|c|c|c|}
\hline Temperature $^{\mathbf{0}} \mathbf{C}$ & \% Ni recovery & \% Cd recovery \\
\hline 25 & 95.50 & 90.10 \\
\hline 40 & 96.00 & 91.00 \\
\hline 50 & 97.10 & 93.00 \\
\hline 60 & 98.20 & 95.50 \\
\hline 70 & 99.00 & 98.50 \\
\hline 80 & 99.01 & 98.30 \\
\hline
\end{tabular}

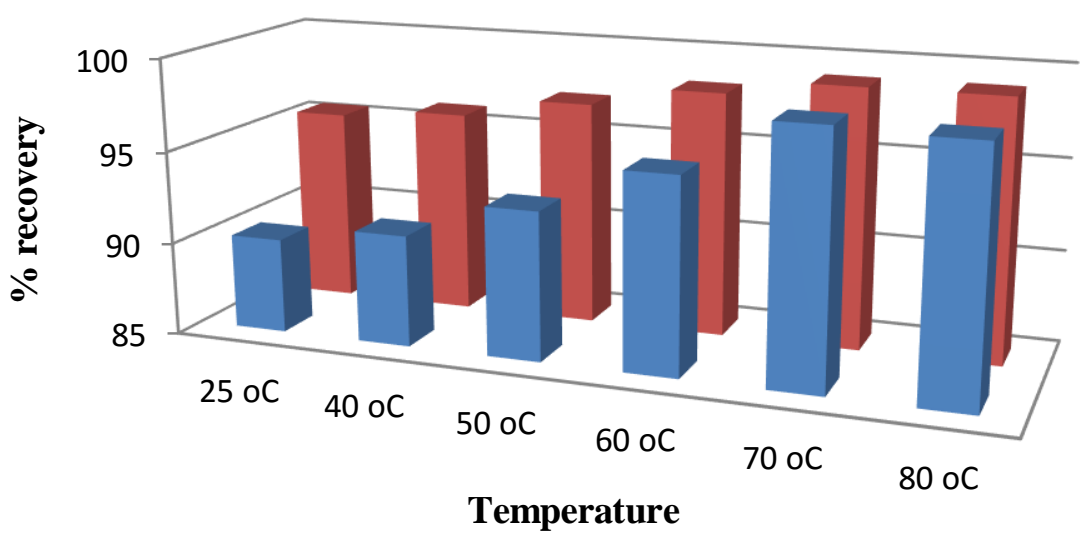

Fig: 6: relationship between temperature Vs. recovery 


\section{Determination of recovered Cadmium and Nickel from spent alkaline batteries using acidic solutions and AAS measurements}

\section{Ahmed M. Saeed, Areej A. Jarullah and Mohammed J. Mohammed}

\section{2 - Precipitation studies:}

\section{1 - Precipitation of iron:}

In this set of experiments the precipitation of iron from leaching solution was investigated. Different types of solution were used to carry out this study. The solutions have a concentration of $20 \% \mathrm{NH}_{4} \mathrm{OH}$ and $1 \mathrm{M} \mathrm{NaOH}$ were used for selective precipitation of iron ion at different $\mathrm{pH}$ (table 9 and figure 7). The results obtained revealed that the precipitation of iron from leaching solutions by using ammonium hydroxide was reaching its highest precipitation percentage values at $\mathrm{pH} 3$ for nickel solution and $\mathrm{pH} 4$ for cadmium solution. Also the results indicating that the precipitation percentages were reached its highest values at $\mathrm{pH} 4$ for ( $\mathrm{Ni}$ and $\mathrm{Cd}$ ) using sodium hydroxide as precipitating agent. The lose percentages of the metals were reached its highest value at $\mathrm{pH} 4$, as shown in figure 6 . The acidity of precipitation of iron from the leaching solution was considered at $\mathrm{pH} \mathrm{3,} \mathrm{using} \mathrm{a} \mathrm{sodium}$ hydroxide solution as a precipitating agent for these reasons:

1- To avoid the uses of ammonium hydroxide, which is need special equipment and conditions, due to the production gases?

2- To avoid the precipitation of $\left[\mathrm{NiSO}_{4}\left(\mathrm{NH}_{4}\right)_{2} .6 \mathrm{H}_{2} \mathrm{O}\right]$ salt [23].

3- To minimize the lose percentage value of $\mathrm{Ni}$ and $\mathrm{Cd}$.

4- To minimize the addition of a large quantity of solution, this causes impurities in the solutions.

Table. 9: the results obtained from iron precipitation study.

\begin{tabular}{|c|c|c|c|c|c|c|c|c|}
\hline \multirow{3}{*}{ pH } & \multicolumn{4}{|c|}{ Nickel precipitation results } & \multicolumn{4}{|c|}{ Cadmium precipitation results } \\
\hline & \multicolumn{2}{|c|}{$20 \% \mathrm{NH}_{4} \mathrm{OH}$} & \multicolumn{2}{|c|}{$1 \mathrm{M} \mathrm{NaOH}$} & \multicolumn{2}{|c|}{$20 \% \mathrm{NH}_{4} \mathrm{OH}$} & \multicolumn{2}{|c|}{$1 \mathrm{M} \mathrm{NaOH}$} \\
\hline & $\begin{array}{c}\% \mathrm{Fe} \\
\text { precipitate }\end{array}$ & $\begin{array}{c}\% \mathrm{Ni} \\
\text { loses }\end{array}$ & $\begin{array}{c}\% \mathrm{Fe} \\
\text { precipitate }\end{array}$ & $\begin{array}{c}\% \mathrm{Ni} \\
\text { loses }\end{array}$ & $\begin{array}{c}\% \mathrm{Fe} \\
\text { precipitate }\end{array}$ & $\begin{array}{l}\% \mathrm{Cd} \\
\text { loses }\end{array}$ & $\begin{array}{c}\% \mathrm{Fe} \\
\text { precipitate }\end{array}$ & $\begin{array}{l}\% \mathrm{Cd} \\
\text { loses }\end{array}$ \\
\hline 1 & 57.30 & 1.80 & 70.79 & 2.00 & 19.23 & 1.90 & 51.54 & 2.00 \\
\hline 2 & 68.54 & 2.00 & 77.53 & 2.70 & 32.31 & 2.10 & 72.31 & 2.40 \\
\hline 3 & 83.15 & 3.00 & 85.20 & 3.50 & 61.00 & 2.50 & 87.69 & 2.50 \\
\hline 4 & 83.15 & 5.00 & 86.52 & 5.20 & 86.15 & 3.00 & 89.23 & 3.00 \\
\hline
\end{tabular}


Determination of recovered Cadmium and Nickel from spent alkaline batteries using acidic solutions and AAS measurements

Ahmed M. Saeed, Areej A. Jarullah and Mohammed J. Mohammed

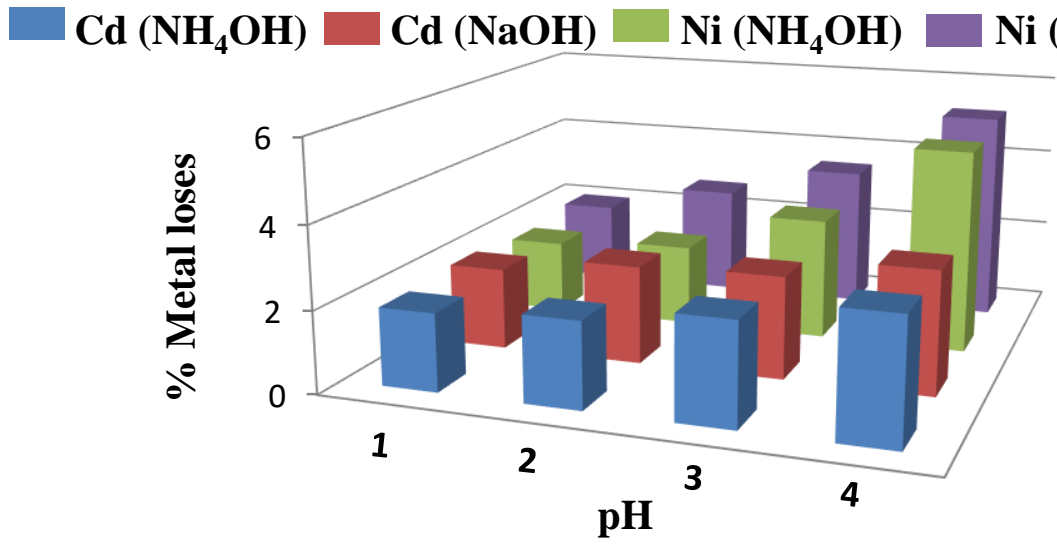

Fig: 7: releatioship between pH Vs. metals loses

\section{2 - Precipitation of metals $(\mathrm{Ni}$ and $\mathrm{Cd})$ studies:}

\subsection{1 - Effect of $\mathrm{pH}$ on precipitation:}

In this set of experiments the precipitation of $\mathrm{Ni}$ and $\mathrm{Cd}$ from free iron leaching solution was investigated. A solution has concentration $2 \mathrm{M} \mathrm{NaOH}$ was used for selective precipitation of iron ion at different $\mathrm{pH}$ (Table 10). The results obtained indicated that the precipitation percentages of $\mathrm{Ni}$ and Cadmium from leaching solutions were reached its highest precipitation values at $\mathrm{pH} 11$ and 10.5 respectively. The lose percentages values of the metals were decreased as value of solution $\mathrm{pH}$ was increased, as shown in figure 8 .

Table. 10: the results obtained from pH study.

\begin{tabular}{|c|c|c|c|c|}
\hline $\mathbf{p H}$ & \%Ni precipitate & \%Ni loses & \%Cd precipitate & \%Cd loses \\
\hline 7 & 66.90 & 33.10 & 60.00 & 40.00 \\
\hline 8 & 67.40 & 32.60 & 65.40 & 34.60 \\
\hline 9 & 81.10 & 18.90 & 72.90 & 27.10 \\
\hline 10 & 91.10 & 8.90 & 82.00 & 18.00 \\
\hline 10.5 & 92.30 & 7.70 & 90.20 & 9.80 \\
\hline 11 & 94.00 & 6.00 & 90.60 & 9.40 \\
\hline
\end{tabular}


Determination of recovered Cadmium and Nickel from spent alkaline batteries using acidic solutions and AAS measurements

Ahmed M. Saeed, Areej A. Jarullah and Mohammed J. Mohammed

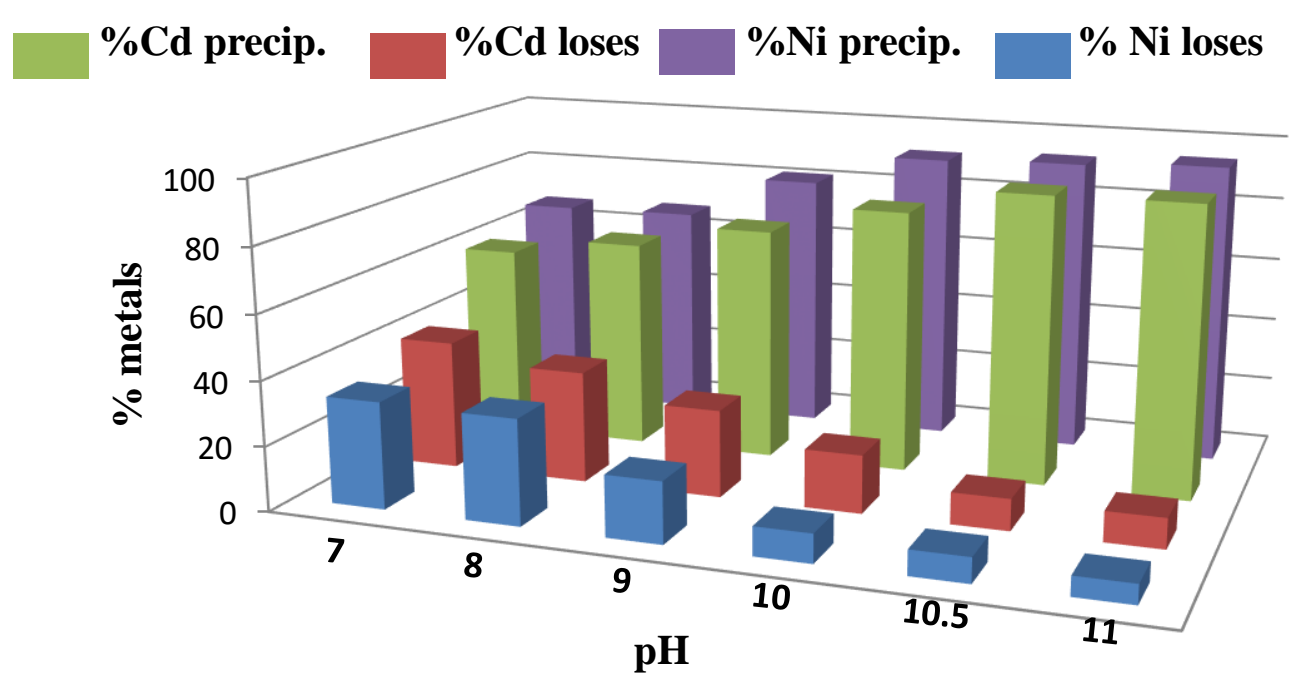

Fig: 8: relationship between pH Vs. \% metals precipitate or lose

\subsection{2 - Effect of precipitation time:}

In this study the effect of precipitation time on the precipitating process of $\mathrm{Cd}$ and $\mathrm{Ni}$ was investigated. A solution of sodium hydroxide has a concentration of $2 \mathrm{M}$ was used for the precipitation of $\mathrm{Cd}$ and $\mathrm{Ni}$ at different time (Table 11 and figure 9). The obtained results indicate that the precipitation percentages were increased as the time of precipitation was increased until reached 120 min., after that the value of increasing being small or near constant.

Table. 11: the obtained results from precipitation time study.

\begin{tabular}{|c|c|c|}
\hline Precipitation time min. & \% Ni precipitate & \% Cd precipitate \\
\hline 15 & 88.70 & 66.70 \\
\hline 30 & 91.50 & 80.40 \\
\hline 60 & 94.20 & 90.60 \\
\hline 120 & 97.00 & 94.50 \\
\hline 180 & 97.00 & 93.70 \\
\hline
\end{tabular}


Determination of recovered Cadmium and Nickel from spent alkaline batteries using acidic solutions and AAS measurements

Ahmed M. Saeed, Areej A. Jarullah and Mohammed J. Mohammed

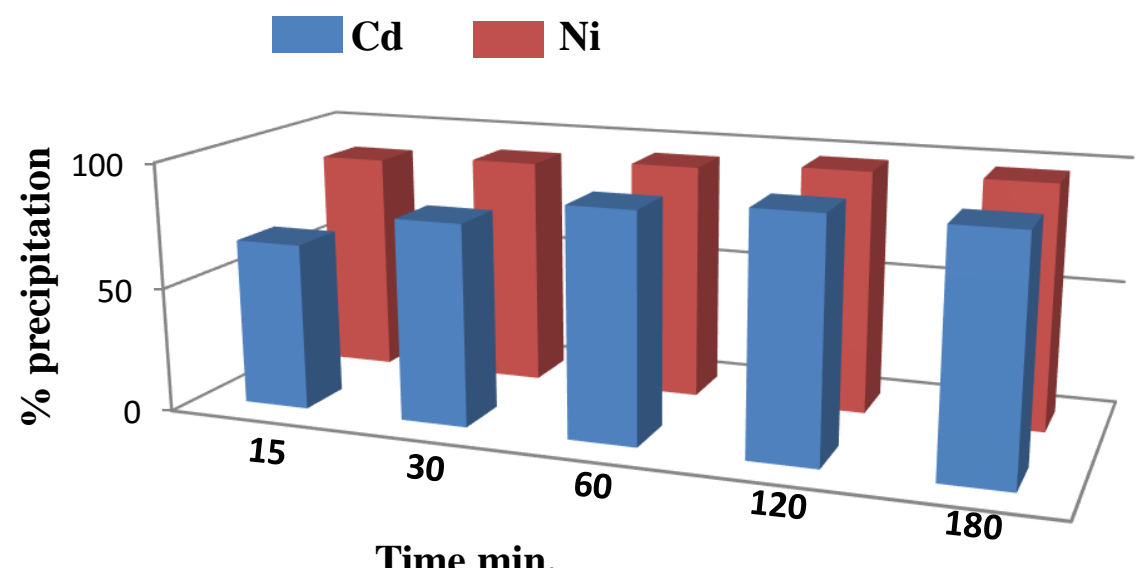

Fig: 9: relationship between time Vs. \% precipitation

\subsection{3 - Effect of temperature:}

In this study the effect of precipitation temperature on precipitation of $\mathrm{Cd}$ and $\mathrm{Ni}$ was investigated. A solution of sodium hydroxide has a concentration of $2 \mathrm{M}$ was used for the precipitation of $\mathrm{Cd}$ and $\mathrm{Ni}$ at different temperatures (table 12 and figure 10). The obtained results indicate that the precipitation percentages were increased as the temperature of precipitation was increased until reaching $25^{\circ} \mathrm{C}$, after that the value of increasing being small or decreased due to the re - solvation process which occurs at high temperature.

Table. 12: the obtained results from temperature study.

\begin{tabular}{|c|c|c|}
\hline Temperature $^{\mathbf{}} \mathbf{C}$ & \% Ni precipitate & \% Cd precipitate \\
\hline 15 & 96.50 & 94.40 \\
\hline 20 & 97.50 & 96.50 \\
\hline 25 & 99.30 & 98.60 \\
\hline 30 & 99.10 & 98.20 \\
\hline
\end{tabular}


Determination of recovered Cadmium and Nickel from spent alkaline batteries using acidic solutions and AAS measurements

Ahmed M. Saeed, Areej A. Jarullah and Mohammed J. Mohammed

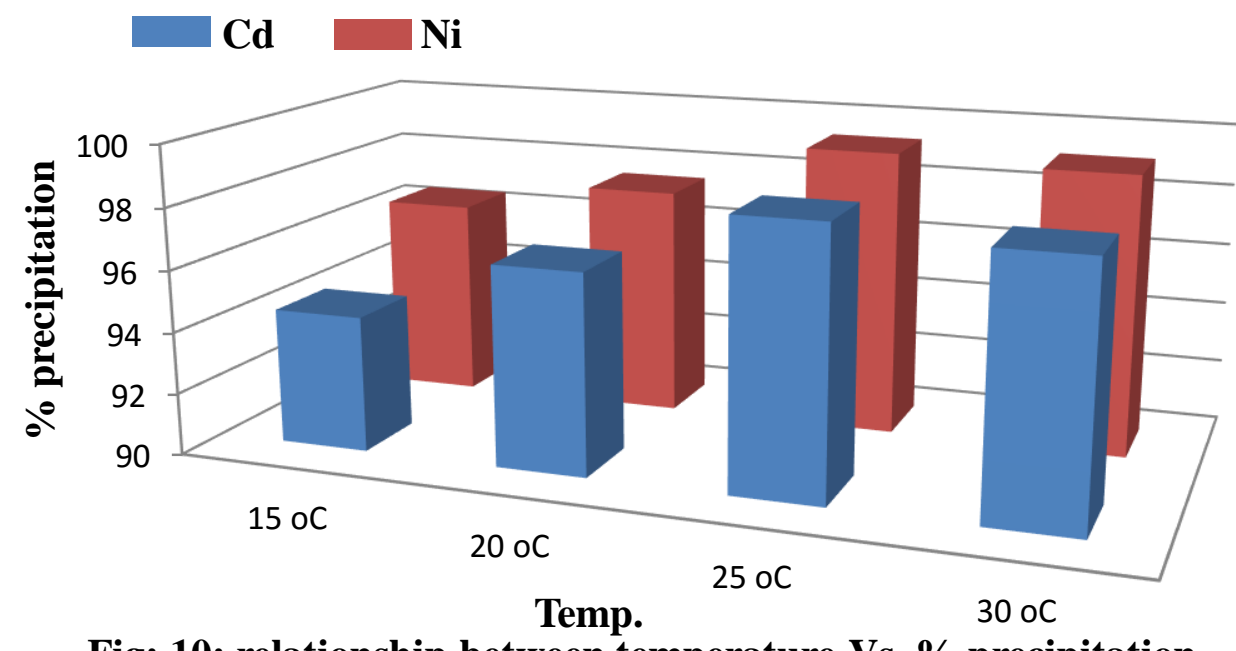

Fig: 10: relationship between temperature Vs. \% precipitation

\section{3 - Purification studies:}

These studies were carried out using double distilled water to remove impurities such as sodium sulfate from nickel precipitate and sodium nitrate from cadmium precipitate. Many parameters affected the purification process such as (time, temperature and number of washing process) were studied. The results obtain are tabulated in table 13. The purity of products $\mathrm{Cd}(\mathrm{OH})_{2}$ and $\mathrm{Ni}(\mathrm{OH})_{2}$ was found to be $98.08 \%$ and $98.23 \%$ respectively.

Table. 13: the obtained results from purification study.

\begin{tabular}{|c|c|c|}
\hline Parameters & Ni results & Cd results \\
\hline Time of washing $(\mathrm{min})$. & 60 & 30 \\
\hline Volume of water $(\mathrm{ml})$ & 25 & 25 \\
\hline Weight of precipitate $(\mathrm{gm})$ & 2 & 2 \\
\hline Temperature of washing ${ }^{\circ} \mathrm{C}$ & 40 & 50 \\
\hline Number of washing process & 4 & 3 \\
\hline Purity of metal hydroxide & $\% 98.23$ & $\% 98.08$ \\
\hline
\end{tabular}




\section{Determination of recovered Cadmium and Nickel from spent alkaline batteries using acidic solutions and AAS measurements}

\section{Ahmed M. Saeed, Areej A. Jarullah and Mohammed J. Mohammed}

\section{Conclusions}

This paper discusses the possibility of nickel, cadmium leaching with sulfuric acid and nitric acid as the first step for recovery of metals from nickel-cadmium spent batteries. The results of the experimental study indicate that leaching with sulfuric acid has the concentration of $5 \mathrm{M} \mathrm{H}_{2} \mathrm{SO}_{4}$ and $5 \mathrm{M}$ nitric acid, as well as liquid/solid ratio of 1:10 and the temperature of $70{ }^{\circ} \mathrm{C}$ could be applied for this purpose. Iron salts in leaching solutions were successfully precipitated with sodium hydroxide in acidic medium ( $\mathrm{pH} 3$ ). The metals were successfully precipitated as hydroxide in basic medium using sodium hydroxide. The studies showed that the high recovery degree of cadmium and nickel from spent $\mathrm{Ni}-\mathrm{Cd}$ batteries is achievable by this hydrometallurgical treatment method. The discussion of results is detailed presented in sections 3 in this paper.

\section{Acknowledgments:}

The authors would like to express him gratitude to the University of Diyala, College of Science, Department of chemistry, for providing lab and research facilities to complete this work.

\section{$\underline{\text { References }}$}

1. A. Agrawal, P. Pathak, D. Mishra, K. Sahu, Solvent mediated interactions for the selective recovery of Cadmium from $\mathrm{Ni}-\mathrm{Cd}$ battery waste, Journal of Molecular Liquids 173, 2012, 77-84.

2. A.M. Bernardes, D.C.R. Espinosa, J.A.S. Tenório, Recycling of batteries: a review of current processes and technologies, Journal of Power Sources 130, 2004, 291-298.

3. J. Frenay and S. Feron, "Domestic battery recycling in Western Europe," Proc. of the 2nd Int. Symp. in Recycling of Metals and Engineered Materials, The Minerals, Metals, and Materials Society, Vol. 2. 1990, 639-647.

4. A. Barashev, S. Karelov, S. Mamyachenkov and O. Anisimova, study of the organized recycling of cadmium - bearing secondary raw materials, Metallurgist, Vol. 57,(3-4), July, 2013, $244-246$. 


\section{Determination of recovered Cadmium and Nickel from spent alkaline batteries using acidic solutions and AAS measurements}

\section{Ahmed M. Saeed, Areej A. Jarullah and Mohammed J. Mohammed}

5. R. J. DeLisle, H. E. Martin, and A Wilkerson, U.S. Patent No. 5437705, Device and Process for the Recovery of Cadmium and Nickel, Eveready Battery Company, St. Louis, MO, filed 09.04.1994, issued 01.08.1995, 1- 10.

6. A. L. Melin and V. H. Svensson, U. S. Pat. No. 4401463, Process for the Recovery of Metals from the Scrap from Nickel-Cadmium Electric Storage Batteries, SAB Nife AB, Sweden, filed 09.21.1982, issued 08.30.1983, 1- 6.

7. A. Cox and D. Fray, Recycling of cadmium from domestic sealed NiCd battery waste by the use of chlorination, Trans. Inst. Min. Metall., Sect. C: Miner. Process. Extr. Metall, 108, 1999, 153-158.

8. J. David, Nickel-cadmium battery recycling evolution in Europe," Power Sources, No. 57, 1995, 71-73.

9. H. Kui, L. Jia, and X. Zhenming, Characterization and Recycling of Cadmium from Waste Nickel-Cadmium Batteries, School of Environmental Science and Engineering, Shanghai Jiao Tong University, PRC 2010, 70 -74.

10. A. Agrawal, P. Pathak, D. Mishra, K. Sahu, Recovery of metal values from spent nickelcadmium rechargeable batteries by solvent extraction route, Proceedings of the XI International Seminar on Mineral Processing Technology (MPT-2010) Editors: R. Singh, A. Das, P.K. Banerjee, K.K. Bhattacharyya and N.G. Goswami (C) NML Jamshedpur, pp. 1195-1201.

11. M. Burylin, Z. Temerdashev, A. A. Pupyshev, A. A. Kaunova, S. A. Obogrelova, Thermodynamic modeling of the thermal stabilizing effectiveness of metal-containing modifiers in an activated carbon matrix for electrothermal atomic absorption spectrometry, Journal of Applied Spectroscopy, Vol. 73,(5), 2006, 760 - 767.

12. A. Babakhani, F, Rashchi, A. Zakeri and E. Vahidi, Selective separation of nickel and cadmium from sulfate solutions of spent nickel - cadmium batteries using mixtures of D2EHPA and Cyanex 302, Journal of Power Sources 247, 2014, 127-133.

13. E. Rudnik and M. Nickel, Hydrometallurgical recovery of cadmium and nickel from spending Ni-Cd batteries, Hydrometallurgy 89, 2007, 61-71. 


\section{Determination of recovered Cadmium and Nickel from spent alkaline batteries using acidic solutions and AAS measurements}

\section{Ahmed M. Saeed, Areej A. Jarullah and Mohammed J. Mohammed}

14. Bernardes, A.M., Espinosa, D.C.R. and Tenório, J.A.S., Recycling of batteries: a review of current processes and technologies. J. Power Sources 130, 2004. 291-298.

15. Freitas, M.B.J.G., Rosalem, S.F.. Electrochemical recovery of cadmium from spent NiCd batteries. J. Power Sources 139, 2005, 366-370.

16. K. Shangri and Delmas, F., New flow-sheet for the recovery of cadmium, cobalt and nickel from spent $\mathrm{Ni}-\mathrm{Cd}$ batteries by solvent extraction. Hydrometallurgy, 52, 1999, $267-287$.

17. Pandey, R.K., Mishra, Shikha, Tiwari, Sanjay, Sahu, P., Chandra, B.P., Comparative study of performance of CdTe, CdSe and CdS thin films-based photoelectrochemical solar cells. Sol. Energy Mater. Sol. Cells 60 (1), 2000, 59 -72.

18. Reddy, B.R., Priya, D.N., Park, K.H., Separation and recovery of cadmium(II), cobalt(II) and nickel(II) from sulfate leach liquors of spending $\mathrm{Ni}-\mathrm{Cd}$ batteries using phosphorus based extracts. Spear. Purif. Technol. 50, 2006, 161-166.

19. Denise Crocce Romano Espinosa, Jorge Alberto Soares Ten’orio, Recycling of nickelcadmium batteries using coal as reducing agent, Journal of Power Sources 157, 2006, 600-604.

20. Kulchaya Tanong, Lucie Coudert, Guy Mercier, Jean-Francois Blai, Recovery of metals from a mixture of various spent batteries by a hydrometallurgical process, Journal of Environmental Management 181, 2016, 95 - 107.

21. Claire Hazotte, Nathalie Leclerc, Eric Meux, François Lapicque, Direct recovery of cadmium and nickel from Ni-Cd spent batteries by electro assisted leaching and electrodeposition in a single-cell process, Hydrometallurgy, Volume 162, June 2016, 94-103.

22. D. A. Katskov, B. V. L'vov, (1969), the atomic absorption determination of ultramicroamounts of cadmium using a graphite cell, Journal of Applied Specroscopy, Vol.10 (5), $588-589$.

23. Ahmed, M. Saeed and M. Al - Sabti, Recovery of Nickel from Burned Fuel Waste, Journal of the college of basic education, vol. 55, 2008, $58-68$. 